\section{Magellan arrives; all systems go}

\section{Washington}

AFTER a string of messy failures, the National Aeronautics and Space Administration (NASA) got a rare dose of good news last week when the Magellan radarmapping probe flawlessly entered orbit around Venus. After two weeks of sensor testing, the craft will begin a 243-day mapping mission that will record Venus's hidden surface in near-photographic quality.

The \$744-million, 3.7-ton probe was launched last May from the space shuttle Atlantis. Last week, after an 83-second braking manoeuvre, it entered an elliptical polar orbit that will allow it to cover 70-90 per cent of Venus' surface. First data are expected to be released on 27 August. Magellan is the fourth craft to orbit Venus. A US Pioneer and two Soviet probes have already mapped much of the planet at somewhat lower resolution. But Magellan, with a high-performance radar-imaging system built by Hughes Aircraft Company, will provide surface information more detailed than currently exists for Earth's ocean floor (see Nature 346, 525; 9 August 1990).

Christopher Anderson

\section{CZECHOSLOVAK ENVIRONMENT}

\section{Clean-up begins}

\section{Prague}

Czechoslovakia underlined its commitment to cleaning up the environment earlier this month when it created a Federal Committee for the Environment, the first such organization in its history. The government gave sweeping powers to Environment Minister Josef Vavrousek, who will try to improve the situation drastically by the end of the 1990s.

At the same time, the government recited a litany of bad news, the worst of which was that Czechoslovakia would probably not be able to keep its promise to reduce sulphur dioxide emissions. As signatories to the 1979 Geneva Clean Air Convention, Czechoslovakia and 20 other European countries promised a 30 per cent reduction in 1980 sulphur dioxide emission levels by 1993. And Czechoslovaks have an expected life span five to seven years shorter than people in the industrial West while seven per cent of national income is lost through environmental damage.

The environment continues to be the highest priority with the Czechoslovak population, even above money and jobs.

But things may change when the state intervenes to shut down heavily polluting factories or reduces the availability of goods. In the June elections the Green Party did not receive the five per cent of votes that would have guaranteed it a seat in parliament.

Veronika Maxová

\title{
Space policy goes green
}

\section{Washington \& London}

CONCERN over climate change and environmental degradation is driving a fundamental shift in the rules of international space collaboration, according to officials now negotiating a new policy on scientific data exchanges. European Space Agency (ESA) partners say the requirement that projects should at least partially pay for themselves - a position most strongly argued by Britain and France - is likely to be abandoned for missions of environmental importance, such as the $\$ 40,000$-million Earth Observing System (EOS).

The decision appears to remove the last obstacle to full international participation in EOS, a series of large climate-monitoring satellites that will begin operation later this decade. Until recently, EOS partners had been deadlocked over the questions of who should get the data and at what cost. But officials now say that a resolution passed at last month's G7 summit meeting in Houston has paved the way for agreement on free access to EOS data, at no more than minimal reproduction costs, for all qualified researchers.

Agreement by EOS partners to a freeaccess policy for the project's data will be a victory for the United States and Japan, which have argued that all researchers who agree to publish their results in the open literature should get EOS data free. Although ESA policy is still under negotiation, the agency's standard position has been to allow only participating researchers to get free data. Other scientists and commercial entities traditionally pay for the data, in part to allow ESA and its partners to recoup costs. Even within ESA, however, the issue is debated.

Britain is one of the strongest advocates of commercial space. "What we mean is that we should be in space for a purpose, not just to be in space", says one official at the British National Space Centre (BNSC). That purpose has historically been to make money, a position that has put Britain at odds with some of its ESA partners.

But in recent months, in line with the Houston summit resolutions, commercial concerns have been eclipsed by the concept of a national responsibility for environmental data. "What we're realizing is that when it comes to the environment, the government and the taxpayer should pay for the data," says the BNSC official. That Britain, the country that has fought hardest for a return on its space investment, is considering making an exception for environmental data is seen as an important step towards a uniform ESA data policy of open access.

ESA partners are currently negotiating a data policy for ERS-1, the first satellite of the agency's Earth Remote Sensing (ERS) programme. The satellite, which will be launched next year, will probably be operated according to a compromise policy in which non-participating researchers will be invited to submit research proposals. Approval by ESA will automatically bring free access to data. Other researchers and commercial entities will have to pay an as yet undetermined access fee for the ERS-1 data.

Guy du Chossois, ERS mission manager in ESA's Paris headquarters, says that the ERS policy reflects a general trend away from a strict commercial approach to something more flexible. Although much of the shift is due to a growing sense of environmental responsibility, the fact that satellite data have rarely been profitable has not escaped ESA's attention. Last year, the US Landsat programme - the largest commercial Earth observation effort - was saved from cancellation only after the White House decided to bail it out with federal funds. And a US experiment in commercializing data from a space-borne wide-field camera was recently ended after it was revealed that total receipts had amounted to less than a thousand dollars. "Everybody knows that you can't recoup your costs", du Chossois says.

Current US policy is to give data freely to qualified researchers in any country that agrees openly to share its Earth-science data and participate in international environmental research programmes. EOS, which will consist of 15 large platforms (six from the United States, six from ESA and three from Japan), is designed to make simultaneous observations with a number of different instruments. To allow scientists to combine data from several instrument, the National Aeronautics and Space Administration (NASA) has decided for the first time to abandon its policy of allowing principal investigators to have a period of exclusive use of the data.

Researchers stress that a nondiscriminatory policy on data access is doubly important for an environmental initiative that spans the globe. Although Brazil, for example, is not a partner in the EOS programme, data from the Brazilian rain forests are a crucial part of the climate change equation. Forcing Brazilian scientists to pay for data would "smack of colonialism", and could result in Brazil charging for its ground-based data, says Robert Gurney, an EOS principal investigator at the University of Reading. And influencing environmental policies in the developing nations is far easier when their scientists are participating equally in global change research, he points out.

Christopher Anderson \& Peter Aldhous 